\title{
COOLING LOAD ESTIMATION OF A MULTI-STOREY BUILDING: A HEAT TRANSFER APPROACH
}

\author{
Zafar Alam ${ }^{1 *}$, Mohd Amir ${ }^{2}$ Mohammad Mansoor ${ }^{3}$ and Mohammad Jamil Ahmad \\ 1,2,3,4 Mechanical Engineering Department ,Aligarh Muslim University, Aligarh, India. 202002 \\ * Author corresponding Email: zafaralamalig003@gmail.com
}

D.O.I - 10.51201/JUSST/21/05159

http://doi.org/10.51201/JUSST/21/05159

\begin{abstract}
The key objective of this work is to maintain the pre-determined inside conditions \& to establish thermal equilibrium the prime rate at which heat needs to be detached from the space. Nowadays one of the most serious problems is environmental issues. For this problem, energy utilization by buildings and enterprises are responsible. Markets, Residential houses, commercial buildings, industry, and Infrastructure consume approximately $72 \%$ of the world's energy. Roughly $60 \%$ of a building's total energy necessity is distributed to the plant of air-conditioning installed in a big complex or building that is air acclimatized. To limit energy utilization, accurate prediction of the cooling load are important. The elementary heat transfer concepts are used to manually calculate the cooling load of a multi-storey building. This method is derived from CLTD technique of cooling load estimation. We estimate the cooling load at the extreme conditions. So, we have taken the outside conditions as relative humidity $54 \%$ and $45^{\circ} \mathrm{C}$ DBT for the month of May during summer. The average outside air velocity during this period is $1.67 \mathrm{~m} / \mathrm{s}$. The significance of this work is to show that, actual cooling load prediction results in less capital cost, investment and energy consumed. Thus, accuracy should be paramount when load calculation is being performed.
\end{abstract}

Keywords: Cooling Load, CLTD, Heat Transfer, Energy, Air-conditioning.

\section{INTRODUCTION}

At definite temperature the human body works best, similar to some additional machine, yet it can not tolerate comprehensive possibility of multiplicities in ecological temperatures similar to machines. With the climate the human body keeps up its warm harmony through three methods of warmth move for example convection, radiation and dissipation. The manner via the person's body 
keeps up himself in agreeable harmony will be by its programmed utilization of at least one of three methods of warmth move. The amount of the warmth disseminated to the environmental factors is equivalent to the warmth put away in body of human through rising the temperature of tissues and the warmth created by digestion of human body. Andersson et al. [1] utilized an improvement adaptation of the structure energy examination PC program BLAST, planned cooling loads and warming for an example private structure at various directions. They distinguished that the complete burdens were exposed to be greater for north than south direction besides in outrageous southern scopes of the U.S. Kulkarni et al. [2] streamlined cooling load for a talk theater in a complex environment in India. The talk theater was arranged at Roorkee $(28.58 \mathrm{~N}, 77.20 \mathrm{E})$ in the northern district of India and had an element of $16 \mathrm{~m} \times 8.4 \mathrm{~m} \times 3.6 \mathrm{~m}$. By a PC reproduction program the cooling limit of cooling framework and month to month, yearly cooling burden was controlled. They announced that the utilization of bogus ceiling, earthenware tiles on floor and rooftop, electro chromic intelligent shaded, air hole of $13 \mathrm{~mm}$, vibrant glass offered the most ideal retrofitting alternative. Suziyana et al. [3] investigated by utilizing cooling load estimation technique and cooling load factor strategy dependent on key handbook ASHRAE 1997, the warmth acquire and determined cooling heap of a Laboratory of Computer and Exceptional Center Rooms in the Malaysia Pahang University Faculty of Mechanical Engineering, From this estimation, it was tracked down that the most noteworthy warmth acquire in the Laboratory Computer Room and in Admirable Center Room is 20458.6 W and 33541.3 W individually and afterward checked by information given by worker for hire of building. Hani H. Sait [4] measured the results from a HAP 4.2 program and the warm burden for the designing structure situated in Rabigh. It was accounted for that, there was a slight distinction between the two outcomes because of characterizing the warm obstruction for the pre-owned windows, dividers material, and rooftop. Yan Suqian et al [5] consistent computation technique are utilized to gauge and analyze cooling heap of workshop of turning, cooling load coefficient strategy was given. He reasoned that aftereffects of two calculations were minimal extraordinary and consistent estimation strategy was more basic \& productive. A. Fouda et al [6] predicted an altered policy for figuring the cooling load for remote structures. The result of this technique were contrasted and the ASHRAE principles and tracked down that the outcomes come from this strategy were more precise and successful. Lin Duanmu et al [7] by utilizing Cooling Load Factor Hourly Method (HCLFM). They anticipated structure cooling load for metropolitan vitality arranging that can give quick and 
reasonable gauge of building cooling load for a huge scope metropolitan energy arranging. In Beijing, China, this technique was applied to a place of business the determined outcomes disclosed that the dynamical pattern of the cooling load is sensible. Christian et al. [8] calculated ascertaining cooling loads in structures the definition of another reasonable sky sun powered radiation model appropriately set up. The principle intention of defining behind the given prototype was to supplant the clear sky model (ASHRAE) of 1967 to conquer the restriction of presented prototype. The different prototype is determined in two stages. The initial step comprised of discovering from the REST2 model, an allusion irradiance dataset and from a dataset REST2based reference irradiance the subsequent advance comprised of fits. The subsequent models and its organized information were relied upon to be coordinated in the ASHRAE 2009 Fundamentals Handbook. Abdullatif et al. [9] used the reenactment encoding ESP-r to figure cooling hourly loads for three places of business employing environment circumstances in Kuwait. General relapse numeral organizations (GRNN) and investigated to promote HVAC nuclear power stockpiling in private structures just as places of business. For 1997-2000 the cooling load information was employed for testing the neural organizations (NN) and reproducing. For upgrading nuclear power stockpiling in structures dependent on outside temperature records results explained us an appropriately planned NN is a useful asset. Fernando Simon et al. [10] announced that the technique showed great outcomes for cases with low mass envelope, yet uncovered restriction to address warm dormancy effect on the yearly cooling and warming burdens. They likewise utilized the Method of Transfer Function to track load estimations and the approval was assessed by the Standard 140 of ASHRAE, the warm heaps of non-private structures dependent on worked on climate information. Mehmet Azmi et al. [11] explored the impacts of various open air configuration cooling frameworks and conditions on cooling burdens. It is taken for that a critical section of the cooling load bound by external conditions of climate. Considered investigations were contrasted and one another when the cooling loop bounds acquired from the diverse conditions of open air configuration. Tingyao Chen et al. [12] fostered the measurable strategy to suitably decide top cooling loads, for the ordinary choice of groupings of correspondent plan climate boundaries. Results show that level sun powered irradiance determined with the strategy in the scope of 4-20\% higher consistently proposed by ASHRAE, than the deliberate worth in various months. To infer in general intermittent exchange factors reacting to various occasional climate heat sources utilized by Brilliant time arrangement (RTS). Naouel Daouas [13] 
concentrated on energy reserve funds in Tunisian structures and ideal protection breadth in dividers utilizing scientific strategy dependent on Complex Finite Fourier Transform (CFFT) for estimation of warming and cooling diffusion loads allowing for various kinds of divider tones and divider directions. For ideal protection thickness, they expected that divider direction have a little impact, yet additional effective impact on energy investment funds. Investigation exhibited that financial boundaries, similar to protection cost, swelling and markdown rates, energy cost and building life, energy saving and perceptibly affected ideal protection. With the degree-days model, they likewise played out a correlation of the current examination. Hussain et al. [14] assessed the moisture control or transport from the conditioned space using rotary desiccant dehumidifier and compared the results with packed bed dehumidifier. Results obtained in rotary desiccant dehumidifier are more satisfactory then the packed bed dehumidifier. Dehumidifiers are required to control the moisture in air and maintain the quality of the air in the conditioned space.

\section{DATA COLLECTION FOR LOAD CALCULATION}

\subsection{Basic Information}

Some fundamental data which are important to figure cooling load prior to assessing the cooling load of any structure there are, such as structures materials, climate condition, building direction, building dispersing etc. More precise load calculation is achieved by more careful the data.

\subsubsection{Building Location}

The building (multi-story) taken in this work is located in Aligarh and located at $27.91 \mathrm{~N}$ latitude and 78.07E longitude in Aligarh region of Uttar Pradesh, India. It is situated nearby 178 meters above average sea level.

\subsubsection{Climate condition}

Aligarh has a monsoon-influenced humid subtropical climate. The storm period initiates in late June, happening till initial October, carrying great humidity. In April Summers start and in May warm with temperatures cresting. Aligarh gets the greater part of its yearly rainfall of 800 millimeters (31 in) throughout these months. The normal range of temperature is $28-38{ }^{\circ} \mathrm{C}(82-$ $\left.100{ }^{\circ} \mathrm{F}\right)$.). Temperatures at that point decline, range of Temperatures between $5-11^{\circ} \mathrm{C}\left(41-52^{\circ} \mathrm{F}\right)$ 
and winter sets in December, and proceeds till February. Winters in Aligarh are by and large gentle, however 2011-12 encountered the least temperature of $1{ }^{\circ} \mathrm{C}$. The haze and frosty spells are outrageous.

Table 1 provides the high and low average temperatures of Aligarh.

\begin{tabular}{|c|c|c|c|c|c|c|c|c|c|c|c|c|}
\hline \multicolumn{1}{|c|}{ Month } & Jan & Feb & Mar & Apr & May & Jun & Jul & Aug & Sep & Oct & Nov & Dec \\
\hline Average high ${ }^{\circ} \mathbf{C}\left({ }^{\circ} \mathbf{F}\right)$ & 20.6 & 23.6 & 30.0 & 36.8 & 40.1 & 39.3 & 34.6 & 33.2 & 33.8 & 33.0 \\
& $(69.1)$ & $(74.5)$ & $(86.0)$ & $(98.2)$ & $(104.2)$ & $(102.7)$ & $(94.3)$ & $(91.8)$ & $(92.8)$ & $(91.4)$ & $(82.3$ \\
$(8)$ & 22.5 \\
$(72.5)$ \\
\hline Average low ${ }^{\circ} \mathbf{C}\left({ }^{\circ} \mathbf{F}\right)$
\end{tabular}

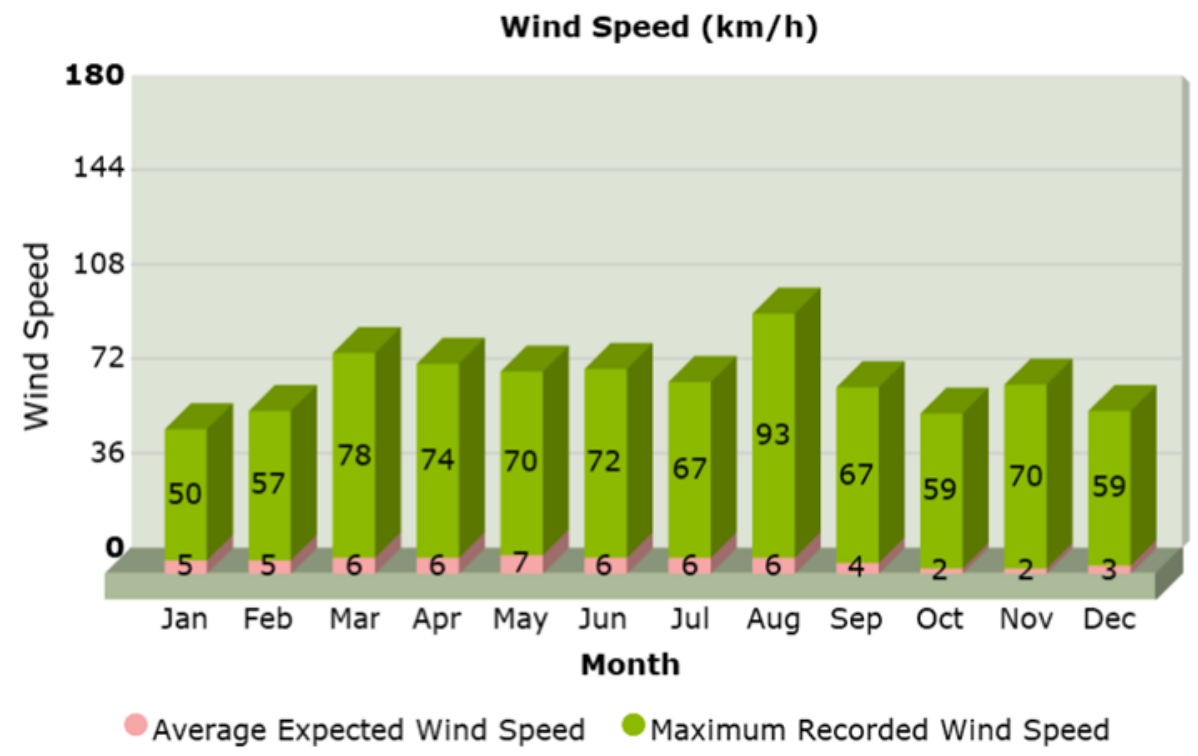

Fig 1 shows the average daily wind speed of Aligarh of each month.

\subsubsection{Building Structures}

At Aligarh Muslim University in Aligarh, India The Maulana Azad Library is the central library. The Multi-storey building of Seven Floors and surrounded by 4.75 acres (1.92 ha) of gardens and lawns. The exterior walls of building consist of $20 \mathrm{~cm}$ concrete block with $10 \mathrm{~cm}$ brick veneer. On inside walls there is plaster of $1 \frac{1}{4} \mathrm{~cm}$. The floor construction is of $20 \mathrm{~cm}$ concrete. The roof is constructed by $4 \mathrm{~cm}$ asbestos with cement board of $20 \mathrm{~cm}$ RCC slab. $5 \mathrm{~mm}$ thick with frame panel are used to make the windows consist of single glass. For simplicity we have shown the results of two divisions in building taken into consideration i.e. Professional Section Division (PSD) and Research Section division (RSD). Dimensions of PSD and RSD in Length, Width \& Height of the room are $36.576 \mathrm{~m}, 12.497 \mathrm{~m} \& 5.35 \mathrm{~m}$ and $30.480 \mathrm{~m}, 11.976 \mathrm{~m} \& 5.35 \mathrm{~m}$ respectively. 


\section{METHODOLOGY}

\subsection{Load Components}

Outer warmth gains show up after the moved warm air power from outdoor warm medium to within the room. The warmth move happens from conduction through outside dividers, ventilation, top rooftop and base ground, sun based heat via openings and entryways and invasion. Different bases are inner warmth acquire comparable individuals, light and electric gear.

\subsubsection{Sensible Heat Gain through Opaque Surfaces}

From outside air to inside air the heat transfer rate is considered via:

$$
\mathrm{Q}=\mathrm{UA}(\Delta \mathrm{T})
$$

where, $\quad A=$ surface area $\left(\mathrm{m}^{2}\right)$

$$
\Delta \mathrm{T}=\text { difference in temperature }\left({ }^{0} \mathrm{C} \text { or } \mathrm{K}\right)
$$

$\mathrm{U}=$ total heat transfer coefficient $\left(\mathrm{W} / \mathrm{m}^{2}-\mathrm{K}\right)$

\subsubsection{Overall heat transfer coefficient}

The overall coefficient of heat transfer ' $U$ ' can be considered by the given formula, when the floor or ceiling and the wall, is fabricated of cover of unlike materials, then

$$
U=\frac{1}{\frac{1}{h_{o}}+\frac{x_{1}}{k_{1}}+\frac{1}{k_{a}}+\frac{x_{2}}{k_{2}} \ldots . . \frac{1}{h_{i}}}
$$

All materials have altered classes of thermo-physical properties; ASHRAE and other handbooks are used to find the common building materials thermo-physical properties.

\subsection{Inside \& Outside surface heat transfer coefficient}

In the above formula for $\mathrm{U}, \mathrm{h}_{\mathrm{i}}$ and $\mathrm{h}_{\mathrm{o}}$ are the interior and exterior heat transfer coefficients of surface or conductances of surface, which take into account both radiation and convection heat transfers. However, for simplicity, the radiative heat transfer is neglected due to its negligible effect in the calculation of inner and outer surface heat transfer coefficients.

From McAdams, 1954 [15]: 


$$
\mathrm{Nu}=0.59 \mathrm{Ra}^{0.25} \mathrm{OR} \mathrm{h}=1.42(\Delta \mathrm{T} / \mathrm{L})^{0.25} \quad \text { for Laminar flow i.e. }\left(\text { for } 10^{4}<\mathrm{Ra}<10^{9}\right)
$$

And, from Warner \& Arpaci, 1968 [16]; Bayley, 1955 [17]:

$$
\mathrm{Nu}=0.1 \mathrm{Ra}^{0.333} \mathrm{OR} \mathrm{h}=1.31(\Delta \mathrm{T})^{0.333} \quad \text { for Turbulent flow i.e. }\left(\text { for } 10^{9}<\mathrm{Ra}<10^{13}\right)
$$

where, $\mathrm{Ra}=$ Raleigh No $=$ Gr $x \operatorname{Pr}$

$$
\begin{aligned}
& \mathrm{Gr}=\text { Grashof No }=\frac{g \beta L^{3} \Delta T}{v^{2}} \quad \text { (all properties to be calculated at film temperature) } \\
& \mathrm{Pr}=\text { Prandtl No }
\end{aligned}
$$

Appropriate heat transfer correlations for forced convection would be utilized to evaluate the external convective heat transfer coefficient $h_{0}$ :

We know that,

$$
\begin{aligned}
& \mathrm{Nu}_{\mathrm{x}}=0.332 \mathrm{Re}_{\mathrm{x}}{ }^{0.5} \operatorname{Pr}^{0.333} \mathrm{OR} \mathrm{Nu_{L }}=0.664 \operatorname{Re}_{\mathrm{x}}{ }^{0.5} \operatorname{Pr}^{0.333} \\
& \left.\qquad \text { for Laminar flow i.e. (for } \operatorname{Re}<5 \times 10^{5}\right)(\text { for } 0.6<\operatorname{Pr}<50)
\end{aligned}
$$

Also, from Holman, 2008 [18]:

$$
\mathrm{Nu}_{\mathrm{x}}=0.0296 \operatorname{Re}_{\mathrm{x}}{ }^{0.8} \operatorname{Pr}^{0.333} \text { for Turbulent flow i.e. (for } 5 \times 10^{5}<\operatorname{Re}<10^{7} \text { ) }
$$

And, from Eckert, 1960 [19]:

$$
\mathrm{Nu}_{\mathrm{x}}=0.185\left(\log \operatorname{Re}_{\mathrm{x}}\right)^{-2.584} \operatorname{Re} \operatorname{Pr}^{0.333}
$$

for Turbulent flow i.e. (for $107<\operatorname{Re}<109$ )

where, $\operatorname{Re}=$ Reynolds Number $=\mathrm{u} \mathrm{L} / v$

$$
\begin{aligned}
& \mathrm{Nu}=\text { Nusselt Number }=\mathrm{h} \mathrm{L} / \mathrm{k} \\
& \mathrm{k}=\text { thermal conductivity of air }
\end{aligned}
$$

\subsubsection{Sensible Heat Gain via Glass}

The heat transfer over glass takes place by transmission heat gain. The following equation can again be taken to estimate glass heat increase:

$$
\mathrm{Q}=\mathrm{UA}(\Delta \mathrm{T})
$$


where, $\quad \Delta \mathrm{T}=$ temperature difference $\left({ }^{0} \mathrm{C}\right.$ or $\left.\mathrm{K}\right)$

$$
\begin{aligned}
& A=\text { surface area of glass exposed to sunlight }\left(\mathrm{m}^{2}\right) \\
& U=\text { complete coefficient of heat transfer for glass }\left(\mathrm{W} / \mathrm{m}^{2}-\mathrm{K}\right)
\end{aligned}
$$

\subsubsection{Heat Gain from Occupants}

By following equations the heat addition from people or occupancy are calculated:

From occupants, Sensible heat gain

$$
\mathrm{Q}_{\mathrm{s}, \text { occupants }}=(\text { Sensible Heat Addition/person }) .(\text { No. of people })
$$

Latent heat gain from occupants

\begin{tabular}{|c|c|c|c|c|c|c|c|c|}
\hline \multirow{4}{*}{ Action } & \multicolumn{8}{|c|}{ Liberated Heat, $\mathrm{W}$} \\
\hline & \multicolumn{8}{|c|}{ Bulb Temperature (Dry), ${ }^{\circ} \mathrm{C}$} \\
\hline & \multicolumn{2}{|c|}{20} & \multicolumn{2}{|c|}{22} & \multicolumn{2}{|c|}{24} & \multicolumn{2}{|c|}{26} \\
\hline & $\mathbf{S}$ & $\mathbf{L}$ & $\mathbf{S}$ & $\mathbf{L}$ & $\mathbf{S}$ & $\mathbf{L}$ & $\mathbf{S}$ & $\mathbf{L}$ \\
\hline Held at rest & 90 & 25 & 80 & 35 & 75 & 40 & 64 & 50 \\
\hline Office work & 100 & 40 & 90 & 50 & 80 & 60 & 70 & 70 \\
\hline Standing & 105 & 45 & 95 & 55 & 82 & 68 & 72 & 78 \\
\hline Eating in restaurant & 110 & 50 & 100 & 60 & 85 & 75 & 75 & 85 \\
\hline Light work in factory & 130 & 105 & 115 & 120 & 100 & 135 & 80 & 155 \\
\hline Dancing & 140 & 125 & 125 & 140 & 105 & 160 & 90 & 175 \\
\hline
\end{tabular}

$$
\mathrm{Q}_{1, \mathrm{occupants}}=(\text { Latent Heat Addition/person }) .(\text { No. of people })
$$

Table 2 Due to occupancy Heat Liberated [20]

\subsubsection{Heat Gain from Lighting Equipment / Appliances}

The heat addition from electric light after the wattage is known is given by:

$$
\mathrm{Q}_{\text {light }}=\text { Overall wattage of light } \mathrm{x} \text { Usage factor } \mathrm{x} \text { Ballast factor }
$$

At the time at which load calculations are performed the usage factor accounts for any lamps that are installed but are not switched on. Its value is usually taken as unity, In case of marketable stores, residences, and factories, whereas it is taken below 0.5 for industrial workshops. For our calculations, it is taken as unity. The load imposed by ballasts used in fluorescent lights takes into 
account via the ballast factor. "For fluorescent lights a typical ballast factor value of 1.25 is taken, while for incandescent lamps it is equal to 1.0 ”.

By the wattage determination of the equipment the heat gain by the appliances is determined:

$\mathrm{Q}_{\text {equipment }}=($ Appliance Load Rating or Overall wattage of equipment $) \times$ Quantity $\times$ CLF

CLF $=1.0$, during weekends, if cooling is off at night, or operation is 24 hours.

\subsubsection{Heat Gain due to Ventilation \& infiltration}

Presence of combustion sources, Extent of cigarette smoking, activity level, etc. are factors on which the quantity of air essential for ventilation hang on.

For calculating the quantity of infiltration, generally air change method is use. Conferring to this method, infiltrated air amount is given via:

$$
\text { Amount of infiltrated air }\left(\mathrm{V}_{\text {inf }}\right)=\frac{\text { Volume of space } \times A_{C}}{60} \mathrm{~m}^{3} / \mathrm{min}
$$

Where, $A_{C}$ is air changes number, value/ hour.

Due to infiltration the sensible heat transfer rate is given by:

$$
\begin{aligned}
\mathrm{Qs}_{\mathrm{s}, \text { inf }} & =\dot{m}_{\mathrm{o}} \mathrm{C}_{\mathrm{p}, \mathrm{m}}\left(\mathrm{T}_{\mathrm{o}}-\mathrm{T}_{\mathrm{i}}\right)=\mathrm{V}_{\mathrm{inf}} \rho_{\mathrm{o}} \mathrm{C}_{\mathrm{p}, \mathrm{m}}\left(\mathrm{T}_{\mathrm{o}}-\mathrm{T}_{\mathrm{i}}\right) \\
& =20.44 \mathrm{x} \mathrm{V}_{\inf \mathrm{x}}\left(\mathrm{T}_{\mathrm{o}}-\mathrm{T}_{\mathrm{i}}\right) \text { watts }
\end{aligned}
$$

Due to infiltration the latent heat transfer rate is given by:

$$
\begin{aligned}
\mathrm{Q}_{\mathrm{L}, \text { inf }} & =\dot{m}_{\mathrm{o}} \mathrm{h}_{\mathrm{fg}}\left(\omega_{\mathrm{o}}-\omega_{\mathrm{i}}\right)=\mathrm{V}_{\text {inf }} \rho_{\mathrm{o}} \mathrm{h}_{\mathrm{fg}}\left(\omega_{\mathrm{o}}-\omega_{\mathrm{i}}\right) \\
& =50000 \times \mathrm{V}_{\text {inf }} \mathrm{x}\left(\omega_{\mathrm{o}}-\omega_{\mathrm{i}}\right) \text { watts }
\end{aligned}
$$

where, $\quad \mathrm{V}_{\text {inf }}=$ infiltration rate $\left(\right.$ in $\left.\mathrm{m}^{3} / \mathrm{min}\right)$

$$
\begin{aligned}
\rho_{\mathrm{o}} & =\text { density of the moist air } \\
\mathrm{C}_{\mathrm{p}, \mathrm{m}} & =\text { the moist air specific heat }
\end{aligned}
$$

$\omega_{\mathrm{i}}$ and $\omega_{\mathrm{o}}=$ specific humidity of inside and outside of conditioned space ( $\mathrm{kg} / \mathrm{kg}$ of dry air) $\mathrm{T}_{\mathrm{o}}$ and $\mathrm{T}_{\mathrm{i}}=$ Outdoor and indoor design temperature respectively $\left({ }^{0} \mathrm{C}\right)$ 


$$
\mathrm{h}_{\mathrm{fg}}=\text { latent heat of vaporization of water }
$$

The infiltration load do not taken into consideration by many engineers. if the ventilation rate is superior to infiltration rate. It is deliberated to be taken care of by ventilation air.

\subsection{Total Cooling Load}

The amount of total room latent heat gain (RLH) and total room sensible heat gain (RSH) is acknowledged as room total heat load (RTH).

$$
\mathrm{RTH}=\mathrm{RLH}+\mathrm{RSH}
$$

\subsubsection{Total Room Sensible Heat Gain}

At a conditioned space Room sensible heat gain is a combination of all types of sensible heat gain i.e.

"RSHG = Sensible heat gain through walls, floors and ceilings + Sensible heat gain through glasses + Sensible heat gain due to occupants + Sensible heat gain due to infiltration air + Sensible heat gain due to ventilation + Sensible heat gain due to lights and fans"[3].

\subsubsection{Total Room Latent Heat Gain}

At a conditioned space Room latent heat gain is a combination of all types of latent heat gain i.e. "RLHG = Latent heat gain due to infiltration + Latent heat gain due to ventilations + Latent heat gain from persons + Latent heat gain due to appliances"[3].

\subsubsection{Room Sensible Heat Factor}

"The ratio of the room sensible heat to the room total heat is defined as Room sensible heat factor" [4].

$$
\mathrm{RSHF}=\frac{R S H}{R S H+R L H}=\frac{R S H}{R T H}
$$

\subsubsection{Total Load in tons}

Total heat gain obtained in Tons:

$$
\text { Total load in tons }=\frac{\text { Total load in Watts }}{35000}
$$




\section{RESULTS}

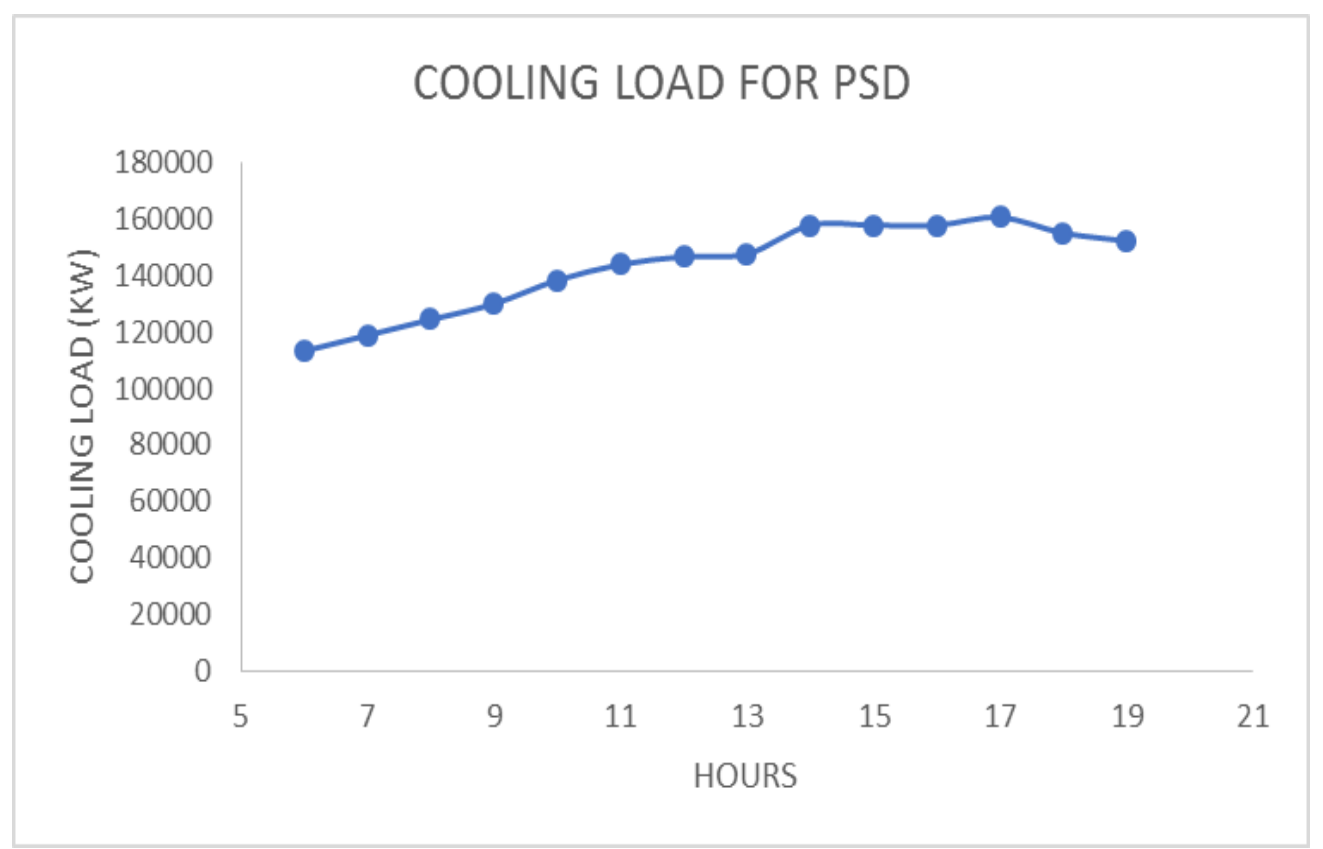

Figure 2: Cooling load for Professional Section Division (PSD) on hottest day of May

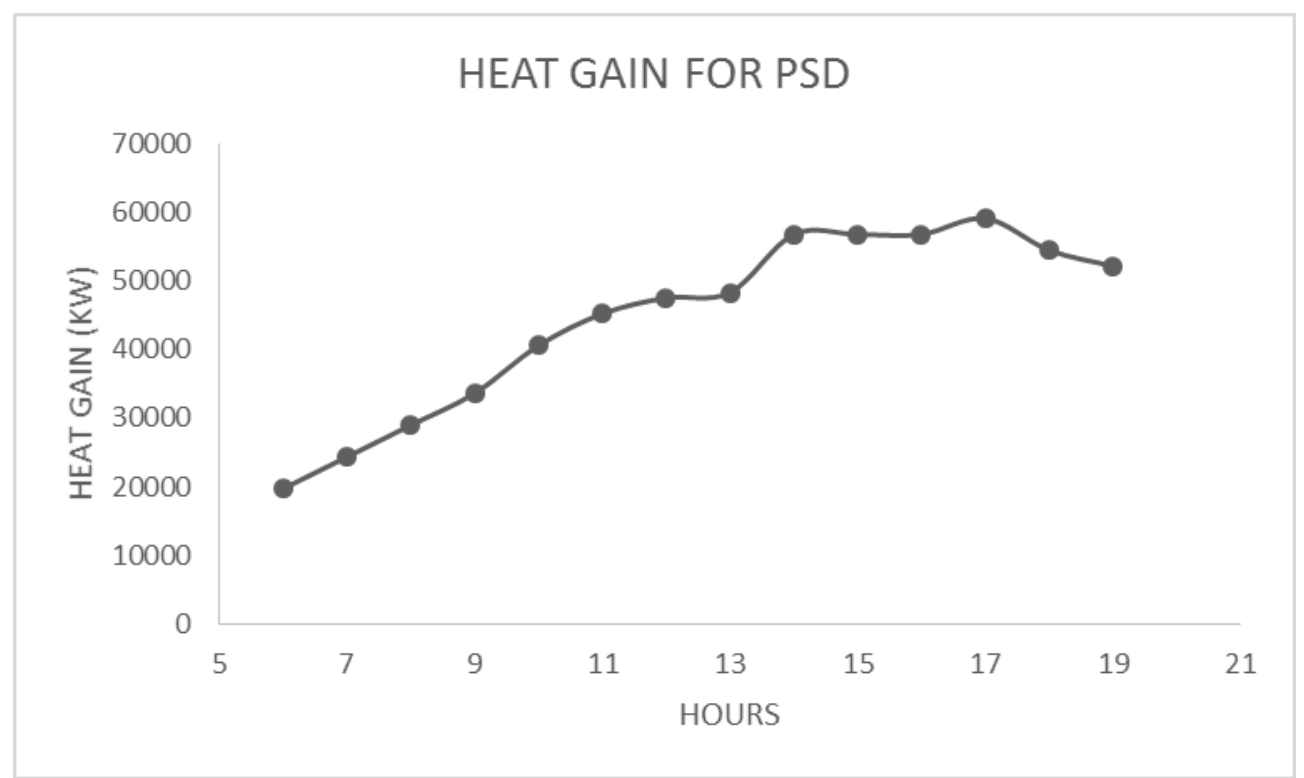

Figure 3: solar heat gain for Professional Section Division (PSD) on hottest of May 


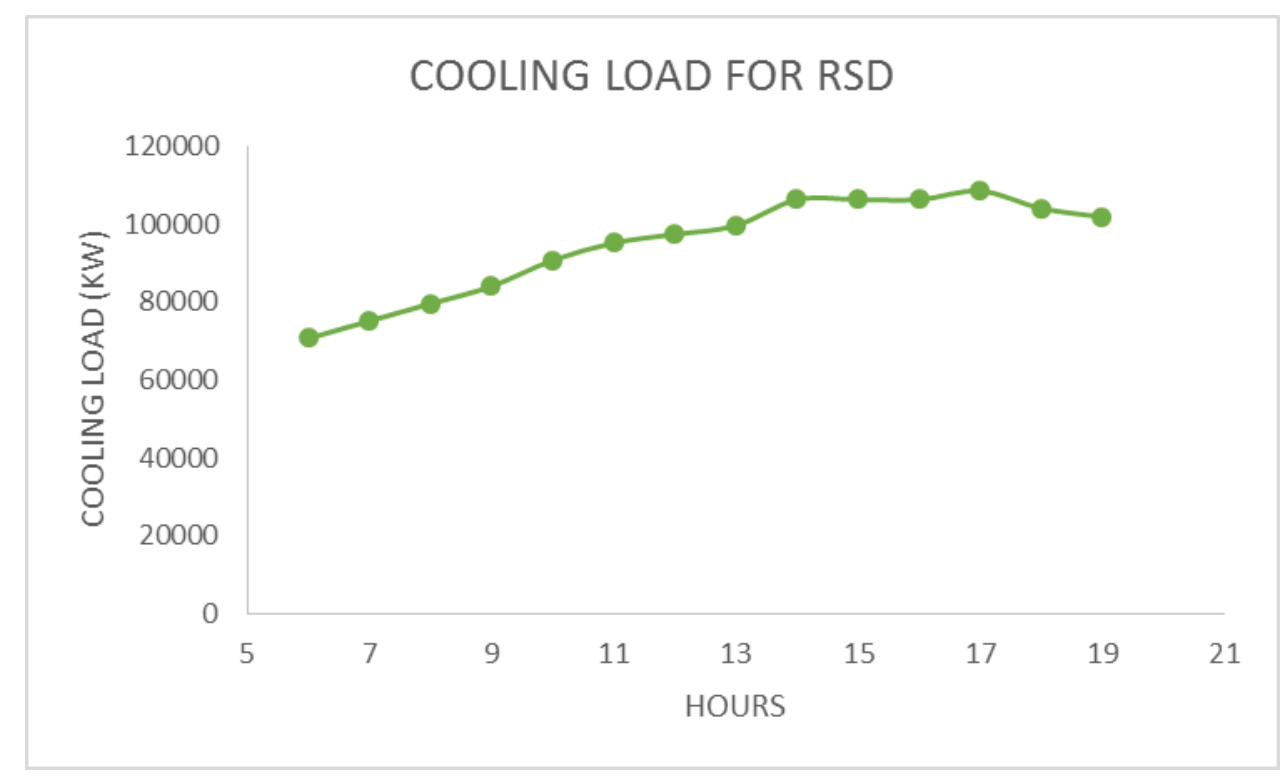

Figure 4: cooling load for Research Section Division (RSD) on hottest day of May

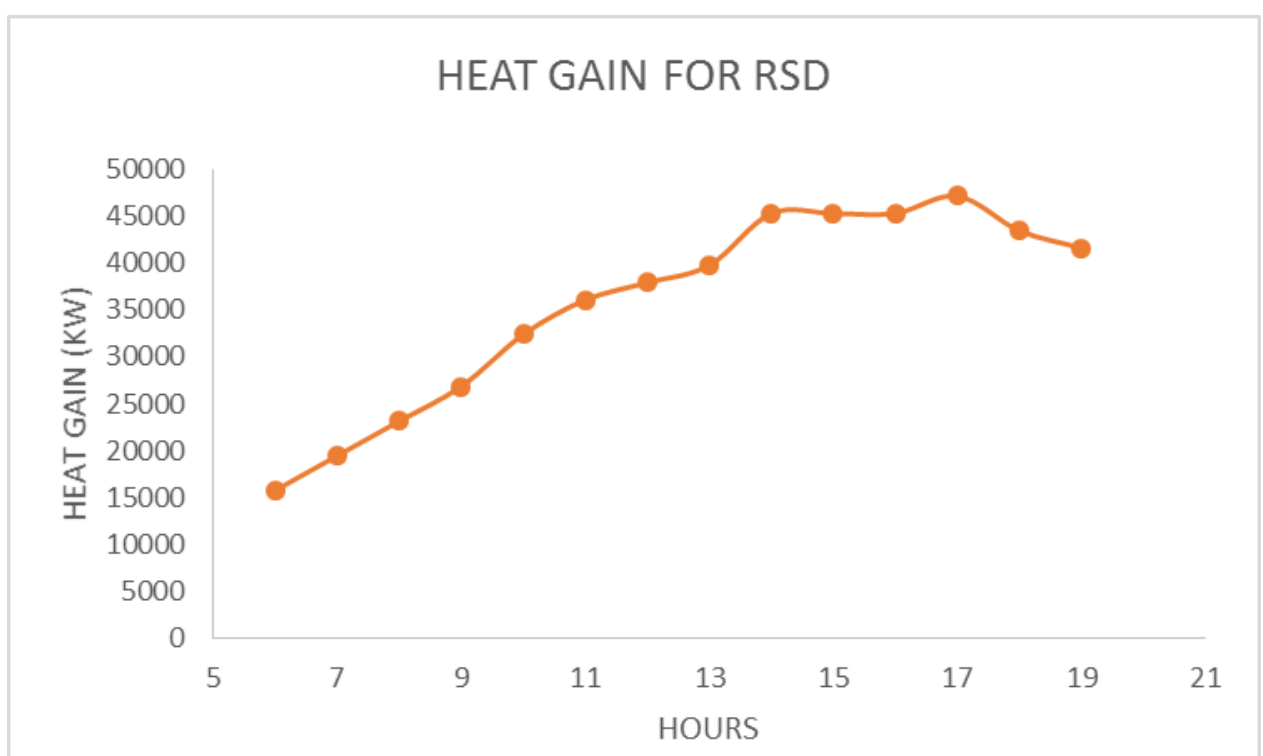

Figure 5: solar heat gain for Research Section Division (RSD) on hottest day of May 


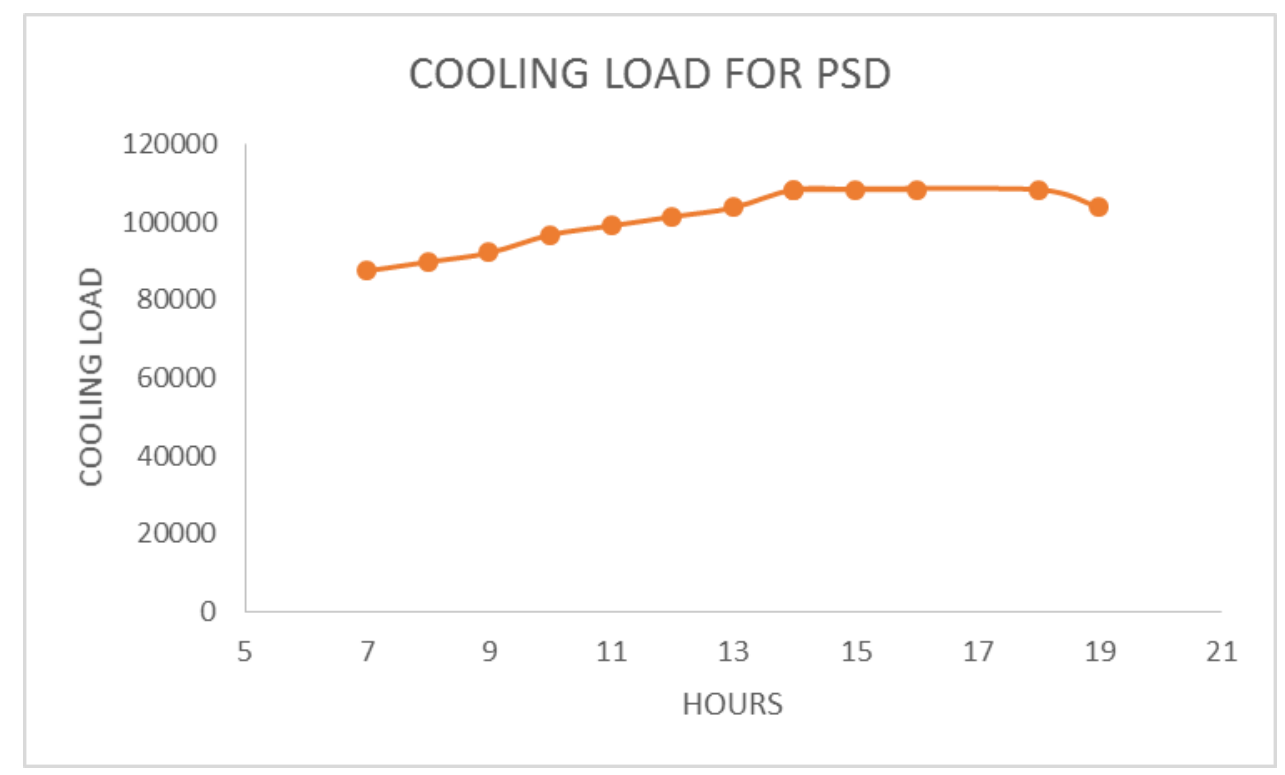

Figure 6: cooling load of Professional Section Division(PSD) on the first day of May

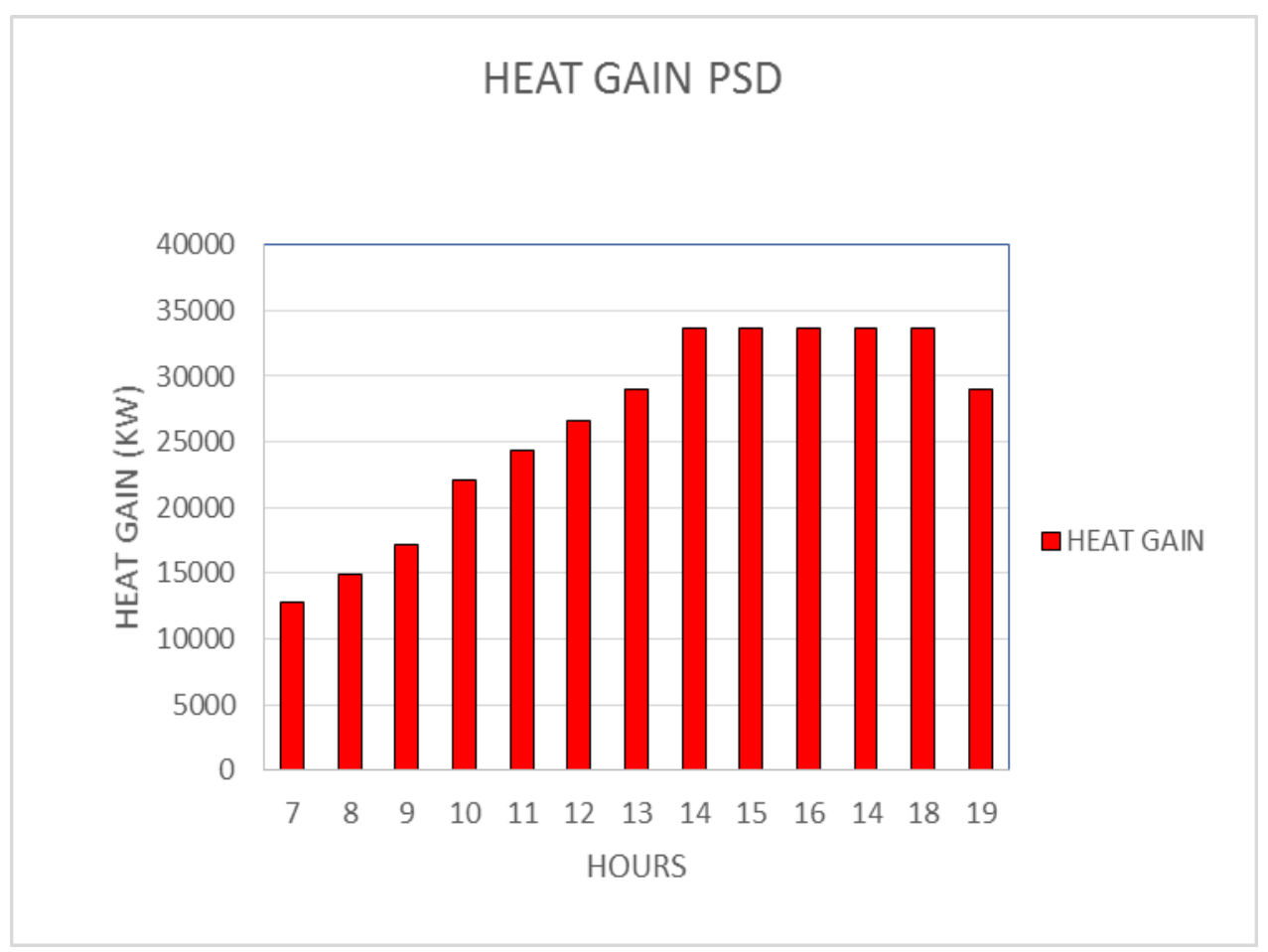

Figure 7: solar heat gain of Professional Section Division (PSD) on the first day of May 


\section{CONCLUSION}

In any space the process of modifying or removing air to remove moisture or maintain temperature is known as ventilation. The example of calculation discussed in the previous section explains how to compute temperature gain in a specific space. The tabulation of heat gain is different, and it has been summarized by the study of heat gain, which took place from 6:00 a.m. to 7:00 p.m.,. Figures 3 and 5 depict a heat gain graph over a specific time period. Heat gain can be divided into two categories of heat gain in the rooms, internal and external heat gain, from six different types of heat addition. Appliances, people, and lighting all contribute to internal heat gain. In the meanwhile, heat conduction, radiation, and ventilation all contribute to exterior heat gain. Figure 3 and 5 depicts exterior heat gain during a specific period of time. figure 2 and 4 depicts the cooling load estimation for different rooms for a specific period of time in a day.

Internal heat gains are fixed as a result of the measurement. This is due to the continuous heat produced by machines such as projectors and computers, in addition to the continuous heat produced by lighting and people. The heat gain pattern from 9 a.m. to 5 p.m. is consistent with its growth and drop, might be seen by the fact that at 10 a.m. and 11 a.m. the heat gain is increased, and reduced for the succeeding two hours. The heat expansion then decreased yet again between 2 and 3 p.m., before increasing between 4 and 5 p.m. Peripheral heat gain, which includes heat gained by radiation, conduction, and air circulation, has a significant impact on the increase in heat gain. It can be observed from figure 1and 3 that maximum cooling load occur when there is a maximum temperature difference and the time maximum solar heat gain because the other parameters (interior gain) are kept constant.

With peak heat gain occurring at $11 \mathrm{a} . \mathrm{m}$. in the morning and $5 \mathrm{p} . \mathrm{m}$. in the afternoon the pattern of heat gain in these two rooms is same. Figure (6-7) shows the same trend for first day of taken month. There isn't much that can be done to reduce heat gain and thereby regulate the power usage of the air conditioning system, Since the heat gain is dependent on external heat gain and the internal components of heat gain are constant,. Reduce the shading coefficient of window glass is a recommended by two techniques that can be used here: laminating the window glass with ultraviolet film and assembling it outside. 


\section{REFERENCES}

[1] Andersson,B., Wayne P. and Ronald K., " The impact of building orientation on residential heating and cooling" , Energy and Buildings,1985; 8; 205-224.

[2] Kulkarni K., P.K. Sahoo and Mishra M., "Optimization of cooling load for a lecture theatre in a composite climate in India" Energy and Buildings, 2011; 43; 1573-1579.

[3] Suziyana M. D., Nina S. N., Yusof T. M. and. Basirul A. A. S., "Analysis of Heat Gain in Computer Laboratory and Excellent Centre by using CLTD/CLF/SCL Method" Procedia Engineering, 2013; 53; $655-664$.

[4] Hani H. Sait, "Estimated Thermal Load and Selecting of Suitable Air-Conditioning Systems for a Three Story Educational Building” Procedia Computer Science, 2013; 19; $636-645$.

[5] Suqian Y., Jiaping L., Ge Xiangrong and Xiang H., "The Research of Cooling Load and Cooling Capacity Calculation Methods of Spinning Workshop" Procedia Environmental Sciences, 2011; 11; $597-603$.

[6] Foudaa A., Melikyan Z., Mohamed M.A. and Elattar H.F., "A modified method of calculating the heating load for residential buildings" Energy and Buildings, 2014; 75; $170-175$.

[7] Duanmu L., Wang Z., Zhai Z.and Xiangli L., "A simplified method to predict hourly building cooling load for urban energy planning" Energy and Buildings, 2013; 58; 281291.

[8] Christian A., Gueymard and Thevenard D., "Monthly average clear-sky broadband irradiance database for worldwide solar heat gain and building cooling load calculations" Solar Energy, 2009; 83; 1998-2018.

[9] Abdullatif E., Ben-Nakhi, Mohamed A., and Mahmoud, "Cooling load prediction for buildings using general regression neural networks" Energy Conversion and Management, 2004; 45; 2127-2141.

[10] Westphal,F.S. and Roberto L., "The use of simplified weather data to estimate thermal loads of non-residential buildings" Energy and Buildings, 2004; 36; 847-854.

[11] Aktacir M.A., Buyukalaca O, and Tuncay Y., "A case study for influence of building thermal insulation on cooling load and air-conditioning system in the hot and humid regions” Applied Energy, 2010; 87; 599-607. 
[12] Tingyao Chen and Zhun Yu, "A statistical method for selection of sequences of coincident weather parameters for design cooling load calculations” Energy Conversion and Management, 2009; 50; 813-821.

[13] Naouel Daouas, "A study on optimum insulation thickness in walls and energy savings in Tunisian buildings based on analytical calculation of cooling and heating transmission loads" Applied Energy, 2011; 88; 156-164.

[14] Hussain, T., Alam, Z., Ahamad, D., Anwar, M. S., Ahmed, S. I., \& Hafiz, A. Dehumidification Analysis of Rotary Solid Desiccant Wheel \& Packed Bed System.

[15] Wawro, N. W., \& McAdams, G. (1954). Cylindromata of major and minor salivary gland origin. AMA archives of surgery, 68(2), 252-261.

[16] Warner, C. Y. (1968). Discussion:"Turbulent Natural Convection from a Vertical Plane Surface”(Cheesewright, R., 1968, ASME J. Heat Transfer, 90, pp. 1-6).

[17] Bayley, F. J. (1955). An analysis of turbulent free-convection heat-transfer. Proceedings of the Institution of Mechanical Engineers, 169(1), 361-370.

[18] Holman, J. P. (2008). Heat Transfer (Si Units) Sie. Tata McGraw-Hill Education.

[19] Eckert, E. R. (1960). Survey of boundary layer heat transfer at high velocities and high temperatures. MINNESOTA UNIV MINNEAPOLIS HEAT TRANSFER LAB.

[20] Colliver, D. G., Gates, R. S., Burks, T. F., \& Zhang, H. (2000). Development of the design climatic data for the 1997 ASHRAE Handbook-Fundamentals. ASHRAE Transactions, 106, PA. 